Running head: THE PSYCHOLOGY OF TALENT MANAGEMENT

Dries, N. (2013). The psychology of talent management: A review and research agenda. Human Resource Management Review, 23 (4), 286-289. 
THE PSYCHOLOGY OF TALENT MANAGEMENT

\begin{abstract}
Across six different streams of the literature (i.e., HRM; I/O psychology; educational psychology; vocational psychology; positive psychology; social psychology) we identify a number of discrepancies (i.e., between practitioner and academic interest; between talent management discourse and practice), theoretical perspectives (i.e., talent as capital; talent as individual difference; talent as giftedness; talent as identity; talent as strength; and talent as the perception of talent), tensions (i.e., object-subject; inclusive-exclusive; innate-acquired; input-output; transferable-context-dependent), and assumptions (i.e., about intuition versus data; about the effects of being labeled 'talented'; about the effects of differential treatment) which we argue can serve as a basis for theory building, methodological advances, and new empirical work. With this review, we hope to join a growing group of talent management scholars pushing to make the transition from a growing into a mature field of study, characterized by widely accepted theoretical frameworks and research designs, and supported by the scholarly community.
\end{abstract}

Keywords: talent management, strategic human resource management, organizational career management, workforce differentiation, high potential employees 
The Psychology of Talent Management: A Review and Research Agenda

"It's the talent, stupid!” exclaim Buckingham and Vosburgh (2001). Indeed, an overwhelming number of human resource (HR) practitioners around the world have reported, across various policy studies, that they believe talent management is one of the most important human capital challenges faced by twenty-first century organizations (e.g. Ashton \& Morton, 2005). Despite over a decade of debate and hype about the 'war for talent' as a pressing concern (Michaels, Handfield-Jones, \& Axelrod, 2001), there has been strikingly little theory development, however — not to mention the lack of robust empirical evidence (Collings \& Mellahi, 2009).

The aim of the current paper is to contribute to the advancement of the study of talent management through a comparative review of the literature. The paper starts with a discussion of the (boundaries of the) talent management phenomenon. We then move on to identify six relevant theoretical perspectives on talent (i.e., talent as capital; talent as individual difference; talent as giftedness; talent as identity; talent as strength; and talent as the perception of talent) which we argue can serve as a basis for theory building, methodological advances, and new empirical work. Across different streams of the academic literature (i.e., HRM; I/O psychology; educational psychology; vocational psychology; positive psychology; social psychology), a number of tensions and assumptions are identified that we believe lie at the heart of the current state of inertia in the academic talent management literature (Lewis \& Heckman, 2006). Tackling these tensions and assumptions through empirical research, we propose, offers a significant opportunity for advancement of the field. We deliberately took a broad approach to our review of the literature — by including unconventional theoretical perspectives that, to date, have rarely been considered in the talent management literature - as the main aim of this paper is to encourage empirical research from as many angles as possible. 


\section{The Talent Management Phenomenon}

As no currently available theory has enough scope to capture its different elements or cause-and-effect relationships, and no methodological approach is considered superior to others, talent management fits the criteria of a 'phenomenon' (Hambrick, 2007). von Krogh, Lamastra, and Haefliger (2009) identify four stages in the evolution of a phenomenon, i.e. embryonic, growing, mature, and declining. Over the course of the last 8 years, the talent management literature seems to have evolved from a marginal topic in the literature to a growing one (see Figure 1). As the bibliometric data shows, however, while there has been a steep increase in the total number of publications on talent management between 1990 and 2013, the scholarly peer-reviewed literature is lagging behind (see also Iles, Preece; \& Chuai, $2010 a$ ). Although over 7,000 articles have appeared to date, only around 100 of them were published in academic journals and identified 'talent management' as a keyword. It appears there is a discrepancy between practitioner and academic interest in talent management (Lewis \& Heckman, 2006)—one that, we will argue, offers significant opportunities for theory building, methodological advances, and fresh empirical work.

— Insert Figure 1 about here -

\section{The War for Talent}

So why is talent management such a hot topic? An important factor is the ubiquitous discourse on the 'war for talent', an expression launched by a group of McKinsey consultants in the 1990s (Michaels et al., 2001). The notion of the war for talent is rooted in two main assumptions. First, that in a knowledge economy traditional sources of competitive advantage are losing their edge whereas human talent is a renewable resource not easily copied or stolen by competitors (Iles, 1997). Second, that attracting and retaining talented people is becoming increasingly difficult as a result of specific demographic and psychological contract trends (Tucker, Kao, \& Verma, 2005). 
Calo (2008) identifies two categories of demographic risk faced by organizations today. The first type of risk, capacity risk, refers to the impending retirement of large numbers of baby boomers and the loss of accumulated knowledge and expertise. In the US and Western Europe, the crux of the issue lies with the impending retirement of large groups of older employees combined with the fact that fewer and fewer young people are entering the workforce. Even though the population in those regions is on average achieving higher levels of education, demand for educated workers is still not being met (Tucker et al., 2005). In other parts of the world (most notably China; see Chuai, Preece, \& Iles, 2008), there is an oversupply of young workers who lack the experience or education to fill key roles (Tulgan, 2001). The second type of risk, productivity risk, refers to the risk of negative effects associated with having an increasing number of older workers on the payroll (e.g., labor cost, skill obsolescence, motivation issues; Calo, 2008).

In addition, the recent literature on psychological contracts (i.e., the beliefs employees hold about the terms of their relationship with their employer; Rousseau, 2001) has taken an interest in the weakening ties between employers and employees. Generally speaking, this literature assumes that as organizations are increasingly less able to promise stable, long-term employment, employees are distancing themselves from their organizations in turn (Tucker et al., 2005). Simultaneously, however, talent scarcities are causing a shift in the power relationship between employers and employees toward the individual employee (Rousseau, 2001). Increasingly, organizations worry that a consumerist attitude is taking hold of their employees - in which the organization is considered a resource to the individual just as much as the other way around (Inkson, 2008).

\section{A Critical Look at Talent Management Discourse}

Interestingly, although the literature on the war for talent is quite specific as to why talent management matters, it is much less specific on what talent management is, exactly 
(Huang \& Tansley, 2012). In fact, the majority of publications on talent management do not offer a formal definition of their central concept (Lewis \& Heckman, 2006), nor does a significant proportion of organizations that have a talent management system in place (Larsen, London, Weinstein, \& Raghuram, 1998; Warren, 2006). Those authors who do offer a definition often fail to define what 'talent' is (e.g., Cappelli, 2008; Duttagupta, 2005; Pascal, 2004), or which specific practices fall under the talent management label (e.g., Ashton \& Morton, 2005; Sloan, Hazucha \& Van Katwyk, 2003) (see Table 1).

— Insert Table 1 about here -

The tendency of the talent management literature to slide off into vague but appealing rhetoric is causing commentators to question whether talent management is not just a management fashion. Management fashions are characterized by conceptual ambiguity, combined with an underlying sense of urgency created by fashion setters (e.g., consultants, business schools, management gurus) which is yet to be legitimized by sound evidence and robust theory (Iles et al., 2010a). As the characteristics of a management fashion seem to apply to talent management — at least at first glance — in recent years several groups of authors have examined whether talent management is just 'old wine in new bottles' (e.g. Chuai et al., 2008; Huang \& Tansley, 2012; Iles et al., 2010a; Tansley, 2011). Unequivocally, they concluded that talent management does in fact add value over other strategic human resource management (SHRM) practices.

Talent management differs from SHRM (i.e., the design and implementation of a set of internally consistent policies and practices which ensure that a firm's human capital contributes to the achievement of its business objectives) in that it is believed to be less egalitarian, and more elitist by definition (Collings \& Mellahi, 2009). Some have said that talent management is to human resource management what gifted education is to education (see Gagné, 2004) - implying that the needs of talented employees are notably different from 
those of the 'average' employee (Ledford \& Kochanski, 2004). More inclusive approaches to talent management are found in the literature as well (e.g., Warren, 2006); several authors have stated, however, that workforce differentiation is the key differentiating principle between talent management and SHRM more generally (Boudreau \& Ramstad, 2005; Collings \& Mellahi, 2009).

While most authors assume that talent management is part of the general HRM strategy of an organization, some have stated that talent management is a 'mindset' and thus, an all-encompassing characteristic of an organization much like organizational culture (e.g., Chuai et al., 2008; Creelman, 2004). In fact, many organizations seem unwilling to explicitly define what talent management does and does not cover, calling it a mindset because they like to use the term 'talent' as a euphemism for 'people' in light of their employer branding (Lewis \& Heckman, 2006). The operationalization of talent management as a mindset is generally advised against, however, as it is difficult to translate into workable practices (Lewis \& Heckman, 2006). Often, the practice of leaving room for 'interpretative flexibility' (Iles et al., 2010a) results in discrepancies between organizational discourse and practice (Gill, 2002). In a study involving eight in-depth case studies, Truss, Gratton, Hope-Hailey, McGovern \& Stiles (1997) found that although organizations prefer to adopt a soft, humanist HRM discourse (focusing on the ' $\mathrm{H}$ ' in HRM), their actual practices are typically more reflective of a hard, instrumental HRM approach (focusing on the ' $R$ ' in HRM), aimed at improving the bottom-line performance of the organization with the interests of the organization prevailing over those of individual employees. Gill (2002) argues that observable discrepancies between discourse and practice pose a serious threat to the reputation of HR practitioners as legitimate business partners - and that although a hard discourse is generally less attractive, it is certainly preferred over an HRM credibility debate. 


\section{From Phenomenon to Theory}

In order to advance the study of talent management it is necessary not only to define the (boundaries of the) phenomenon, but also to identify relevant theoretical perspectives that can serve as a basis to develop new theory or set up new empirical studies. In what follows we discuss different streams of the literature (in HRM and psychology) that we see as relevant to the study of talent management. From these literatures, we distill five key tensions and four conjectural assumptions about talent that can serve as a basis for future research.

\section{Identification of Relevant Theoretical Perspectives on Talent}

For each of the literature streams listed in Table 2 we discuss, consecutively, how it operationalizes talent; what it sees as the most important criterion for talent management; its most important recent research findings; its main (potential) contributions to the talent management literature; and the main gaps that remain to be addressed (see Table 2).

In the HRM literature. The HRM literature operationalizes talent as capital (e.g. Pascal, 2004). According to Sparrow (2009) and Farndale, Scullion, and Sparrow (2010), talent needs to be looked at through four capital lenses: human capital (i.e., the stock of competencies, knowledge, social and personality attributes, embodied in the ability to perform labor so as to produce economic value); social capital (i.e., the sum of the actual and potential resources that can be mobilized through membership in social networks of the organization's actors); political capital (i.e., being known in one's network for getting things done - reputational capital — and the capacity to effectively build constituent support and acquire legitimacy by using traditional forms of power-representative capital); and cultural capital (i.e., long-standing dispositions and habits acquired in the socialization process, transmitted tacitly from one generation of employees to another and into organizational memory). 
A human capital perspective on talent assumes a resource-based view (RBV) of the firm, with an employee's contribution to the organization as the main criterion of interest. An important theoretical framework within the RBV is the HR architecture model developed by Lepak \& Snell (1999). The latter argue that the human capital of any given organization can be categorized along two dimensions - value and uniqueness. Value refers to the potential of the human capital at hand to contribute to its organization's core competence and enhance its competitive advantage. Uniqueness refers to the extent to which the organization's human capital would be difficult to replace (high uniqueness) as opposed to being readily available in the labor market and easily copied by competitors (low uniqueness). Consequently, according to this theoretical perspective talent refers to the human capital in an organization that is both valuable and unique.

The main contribution of the HRM literature to the study of talent management is that it explicates the social exchange relationship between organizations and their employeeswhile 'employment' offers a context for the application of human talent to productive purposes outside the self, 'deployment' of talent refers to the capacity of employees to add value to their organization by contributing to its core competence. In addition, the HRM literature recognizes, more than all other literature streams, that the manifestation of talent in the workplace depends not only on innate factors, but that latent (i.e., hidden, untapped), intervening (i.e., concerted, deliberate), and evolving (i.e., experience-based) components also play a role (see Silzer \& Church, 2009). HRM researchers also tend to be more accepting of subjective evaluations of talent, attempting to achieve reliability through multisource (i.e., 360) designs (Silzer \& Church, 2010) - thus reflecting the importance it attaches to the fit between individual talent and its interpersonal context (Garrow \& Hirsch, 2008).

As discussed earlier, in spite of the popularity of talent management in the HR practitioner literature, there has been surprisingly little empirical research on the topic, and 
many gaps remain (Lewis \& Heckman, 2006). Most of the research that has been done has adopted a single-case study approach (e.g. Remdisch \& Dionisius, 1998), or builds on anecdotal evidence to prescribe best practices (e.g. Ashton \& Morton, 2005). In recent years, there has been an upsurge of research into global talent management (e.g. Farndale et al., 2010), building mostly on theoretical frameworks from the international (cross-cultural) HRM domain. Much less research has been done on the experiences and perceptions of talented (and less talented) employees. Notable exceptions include a handful of studies that have been done on the experiences of employees identified as 'high potentials' (e.g., Björkman et al., 2013; Dries \& Pepermans, 2008), as well as on the consequences of workforce differentiation for advantaged and disadvantaged employee groups (e.g., Marescaux, De Winne, \& Sels, 2013).

— Insert Table 2 about here -

In the psychology literature. Although talent management is typically approached from an HRM lens, different streams of the psychology literature offer interesting theoretical perspectives on talent, as well (Huselid \& Becker, 2011). As Inkson (2008) states, humans are not just 'resources' in the same sense as are non-human resources-hence, they need to be approached from a psychology-, rather than a resource-based view. Psychology is seen as the missing link (i.e., the black box) between HRM strategy and organizational performance, in that employee perceptions, attitudes, and attributions are seen as crucial mediators of the HRM-performance relationship. Although there has been some recent interest in the psychological contract as a lens through which to examine employee perceptions of HRM systems (e.g., Höglund, 2012), in general, the HRM literature has focused primarily on intended and actual, rather than on perceived HRM practices (Wright \& Nishii, 2007). Therefore, we will argue that in order to advance the study of talent management, we must bring in what we know about talent from the psychology literature. 
Industrial-organizational (I/O) psychology. The I/O psychology literature, especially that on personnel selection and performance appraisal, approaches talent from an individual differences perspective, encompassing factors such as cognitive ability, expert knowledge, and personality (e.g., Hough \& Oswald, 2000). Traditionally, within the psychometric paradigm (see Anderson, Lievens, van Dam, \& Ryan, 2004) the primary goal has been to develop assessment methodologies that validly predict candidates' future work performance. Increasingly — and motivated by the same supply-demand dynamics we described earlier in the section on the war for talent-its focus is shifting to a social process paradigm where negotiation about 'i-deals' (i.e., idiosyncratic employment arrangements implying special treatment in that there is a deviation from the standard arrangements; Rousseau, 2001), and applicant reactions to selection procedures (i.e., perceived fairness) take center stage (Anderson et al., 2004).

As is the case with the talent management literature, at its origins the selection and performance appraisal literature was highly phenomenon-driven. Cappelli (2008), for instance, describes how assessment centers were originally developed to meet a practical need, and only later subjected to empirical scrutiny in terms of validity, utility, and potential adverse impact. Today, the I/O psychology field is characterized by a longstanding research tradition in personnel selection (e.g., Anderson et al., 2004), promotion systems (e.g. Ishida, Su, \& Spilerman, 2002), and performance appraisal (e.g., Highhouse, 2008).

An important (and problematic) evolution is that the criterion of predictive validity is becoming increasingly difficult to fulfill as organizations move from job- to competencybased selection paradigms, in which both predictors and criteria are operationalized as dynamic and ever-evolving (i.e., 'bimodal prediction'; Anderson et al., 2004). Consequently, the main issue in adopting this type of prediction paradigm to talent management is the criterion problem-talent for what? (Graen, 2009). 
Educational psychology. The education psychology literature, especially that on gifted education, operationalizes talent as giftedness - i.e., the possession and use of untrained and spontaneously expressed natural abilities in at least one ability domain, to a degree that places an individual at least among the top 10 percent of age peers (Gagné, 2004). The main criterion here is domain-specific excellence (Simonton, 1999).

The recent research within this literature stream focuses on two main themes: first, the early detection of giftedness in schoolchildren, mostly through standardized testing; and second, the issue of specialized, gifted education. The most important contribution of the giftedness literature to the study of talent is its strong focus on concepts, theory building, and causality. Gagné's (2004) Differential Model of Giftedness and Talent (DMGT), for instance, describes how untrained natural abilities (i.e., gifts) across four domains (intellectual, creative, socioaffective, and sensimotor) may or may not be transformed into systematically developed abilities (i.e., talents) in seven fields of human functioning (academics, arts, business, leisure, social action, sports, or technology), through environmental (milieu, people, provisions), intrapersonal (physical and mental traits, goal orientation), developmental (maturation, informal learning, non-institutionalized and institutionalized formal learning), and chance factor 'catalysts'. In their pursuit to make causal statements about the emergence of talent in young adults, giftedness researchers have even gone so far as to partner up with behavioral geneticists to examine emergenic and epigenetic factors determining the onset of observable talent (Simonton, 1999). The giftedness construct is typically separated from other constructs (such as competence) through the use of estimated prevalence in the population as a boundary condition, whereby mild giftedness is said to occur in 1 out of every 10 individuals, and extreme giftedness (with every level of giftedness representing the top 10 percent of the previous level) in 1 out of every 100,000 individuals (Gagné, 2004). 
In spite of its contributions, however, the giftedness literature has little immediate implications for talent management in organizational settings. First of all, research on giftedness focuses exclusively on children and adolescents, implying that talent that has not 'come out' by the onset of adulthood never will; second, it operationalizes giftedness mostly as a score on a normative ability test (such as an IQ test), in doing so equating giftedness with performance on a standardized scale, which has been demonstrated to be a poor criterion for the display of talent in organizational settings (Robinson, Fetters, Riester, \& Bracco, 2009).

Vocational psychology. The vocational psychology literature operationalizes talent as an identity, with vocational self-concept crystallization - i.e., the possession of a clear and stable self-perceptions of one's enduring goals, interests, and talents over the course of one's career (Ibarra, 1999) — as the main criterion of interest.

The vocational psychology literature typically adopts a temporal-dynamic perspective to research, focusing on processes that develop over time as a result of a complex amalgam of intra- and inter-individual influences (e.g., Inkson, 2008). Consequently, it operationalizes the fulfillment of talent as a continuous process without a fixed or predefined criterion. In other words, it advocates that as people develop and evolve, so does their vocational self-conceptand that there is not one ultimate talent-related identity that a person should strive to fulfill (Whitty, 2002).

The study around 'possible selves', in particular, offers interesting avenues for further research on talent (e.g., Markus \& Nurius, 1986). Possible selves are defined as people’s ideas of what they might become (potential self), would like to become (ideal self), fear to become (feared self), or feel they should become (ought-to self) (Whitty, 2002). Experimental research has demonstrated that visualization of the ideal self in a certain area of life (e.g., work), combined with positive feedback from others, results in heightened performance in that area (Oettingen, Marquardt, \& Gollwitzer, 2012). Most of the research in 
the vocational psychology field, however, uses narratives to collect data, rejecting more positivistic research methods (Ibarra, 1999). Therefore, the findings reported in this stream of the academic literature tend to be highly idiosyncratic and difficult to generalize to higher levels of analysis.

Positive psychology. The positive psychology literature operationalizes talent as strengths - i.e., characteristics of a person that allow them to perform well or at their personal best (Wood, Linley, Maltby, Kashdan, \& Hurling, 2011). The ultimate criterion for talent management, according to this perspective, is self-actualization. Self-actualization refers to the realization of one's fullest potential through the accomplishment of everything one is capable of (Bakker \& Schaufeli, 2008).

The positive psychology literature is a branch of the psychology literature that focuses on positive outliers - i.e., people or experiences that deviate from (socially constructed) norms in a positive way (Seligman \& Csikszentmihalyi, 2000). Consequently, it operationalizes talent as those areas in which a person is able to deviate most from the norm - whereas in the other literature streams, most notably the I/O psychology literature, extreme deviation from a norm might be interpreted either as problematic, or as measurement error (Spreitzer \& Sonenshein, 2004). The positive psychology literature studies concepts such as passion (i.e., a strong inclination towards an activity a person likes, finds important, and wants to invest energy in; Vallerand et al., 2003), peak performance (i.e., an episode of superior functioning in which self-actualization is temporarily experienced; Bakker \& Schaufeli, 2008), and loving one's job (i.e., a degree of job satisfaction that far exceeds traditional notions of engagement and commitment; Kelloway, Inness, Barling, Francis \& Turner, 2010), typically linking them to positive health outcomes such as flow, wellbeing, happiness and reduced risk of burnout. It advocates a strength-based approach to talent management - i.e., "the art of recognizing where each employee's areas of natural talent lie, 
and figuring out how to help each employee develop the job-specific skills and knowledge to turn those talents into real performance"-rather than a gap approach focused on the remediation of 'development needs' (i.e., weaknesses) (Buckingham \& Vosburgh, 2001, p. 22).

Somewhat paradoxically, the mission of the positive psychology literature is to apply what can be learned from positive outliers to everyone else (Seligman \& Csikszentmihalyi, 2000). It tends to ignore, however, the fact that the assessment and development of talent in organizations takes place in a normative framework determined by organizational strategy. The assumption of the strength-based approach creating a win-win for both individuals and organizations may be flawed, in that gap-based and exclusive approaches to talent management are often the more cost-effective and efficient solution (Collings \& Mellahi, 2009).

Social psychology. Finally, the social psychology literature, especially that on social cognition, operationalizes talent as the perception of talent. It offers potential for examining the dynamic ways in which expectations and judgments shape what is manifested and discernible as talent, rather than taking an interest in the talent itself (Dominick \& Gabriel, 2009). Consequently, the most important criterion it holds talent management against is rater accuracy (i.e., the maximal avoidance of measurement bias and error; Highhouse,2008). As 'quasirationality' - i.e., a mode of decision making that includes elements of both analytical and intuitive cognitive processes - is believed to be the most common mode of decision making in organizations (Hammond, 1996), it is clear that the avoidance of rater bias should be an important topic in the study of talent management.

The social psychology literature relies mostly on experimental designs, focusing on issues such as rater beliefs, mindsets, and bias, and the effects of feedback and labeling (e.g. of the 'high potential' label) on ratees. Important recent findings include a generalized 
preference for potential (i.e., a phenomenon whereby raters consistently rate people with high potential in a certain domain more positively than people who have already demonstrated good performance in that same domain; see Tormola, Jia \& Norton, 2012); naturalness bias (i.e., the tendency to rank innate over acquired sources of performance; see Tsay \& Banaji, 2011); and incremental induction (i.e., experimental interventions that can alter a rater's mindset so that he or she demonstrates less naturalness bias; see Heslin, Latham \& Vandewalle, 2005).

The contribution of social psychology to the study of talent management is that it brings in the element of social perception - in a way, one could argue that talent that is not recognized or acknowledged does not 'exist' in the sense that it is not acted upon (Dominick \& Gabriel, 2009). In addition, the use of experimental designs allows for controlled manipulation of contextual factors. It is unclear, however, to what extent these experimental findings can be generalized to real-life organizational settings (Heslin et al., 2005).

\section{Tensions in the Literature}

Based on a comparative analysis of all of the above, we identify five tensions in the literature. For each of these tensions, we discuss what the key point of discussion is as regards the operationalization of talent; which practical talent management issue it refers to; the different positions organizations can adhere to; and the implications each different perspective carries for talent management policies and practices (see Table 3).

Rather than the different tensions implying either-or talent management decisions, they each represent a continuum on which organizations can assume a more or less extreme position. Also, the different tensions identified in Table 3 are not completely independent from each —we posit, for instance, that an exclusive perspective on talent will often coincide with a belief that talent is innate and transferable. Nonetheless, we believe that any combination of perspectives ( 32 in total) is possible in theory. 
— Insert Table 3 about here -

Tension between object vs. subject perspectives on talent. This first tension in the literature refers to the important discussion about what, or who, constitutes talent. Subject perspectives on talent imply a focus on the identification and development of talented people. Object perspectives on talent, on the other hand, imply a focus on the identification and development of characteristics of talented people. Although, in practice, the object-subject distinction is difficult to conceive (as the characteristics of people cannot be isolated from them as a whole), it does carry important implications for talent management research and practice (see also Gallardo-Gallardo, Dries, \& González-Cruz, this issue).

First of all, object and subject perspectives on talent imply different theoretical frameworks. While the object perspective has clear links to the aforementioned literatures on human capital (e.g., Farndale et al., 2010; Sparrow, 2009) and the resource-based view (e.g., Iles, 1997; Lepak \& Snell, 1999), as well as on pivotal positions (e.g. Collings \& Mellahi, 2009; Huselid \& Becker, 2011) and individual differences (e.g., Hough \& Oswald, 2000; Ulrich \& Smallwood, 2012), a subject perspective resonates through the literature on high potential employees (e.g., Björkman et al., 2013; Dries \& Pepermans, 2008), the literature on A, B, and C players (e.g., Becker, Huselid, \& Beatty, 2009), and on talent pools (i.e., Boudreau \& Ramstad, 2005; Silzer \& Church, 2010).

Second, object and subject perspectives on talent imply different approaches as to what (or who) talent management should manage, exactly (Iles, Chuai, \& Preece, 2010b). As is indicated in Table 3, when an organization takes an object approach to talent management it is more likely to see competence management and knowledge management as central practices within its integrated talent management system (e.g., Vance \& Vaiman, 2008). Organizations that take a subject approach to talent management, from their side, are more 
likely to rely on succession planning and organizational career management (e.g., Duttagupta, 2005).

Tension between inclusive vs. exclusive perspectives on talent. This second tension in the literature refers to the important discussion about the estimated prevalence of talent in the (working) population. An inclusive perspective on talent departs from the assumption that all people are talented, but in a different way; an exclusive perspective, on the other hand, is built on the premise that some people are inherently more talented (and thus more valuable) than others - at least within the organizational context (see also Gallardo-Gallardo et al., this issue; Iles et al., 2010b). As we discussed in our account of the literature on gifted education, a plethora of norms have been prescribed concerning the estimated prevalence of gifted people in the population as a whole (Gagné, 2004). In the HRM literature as well, several authors have made statements as to the percentage of employees that can (or should) be identified as talented on an annual basis (e.g., Silzer \& Church, 2009; Ulrich \& Smallwood, 2012). Overall, estimates range between $1: 100,000$ and 10 percent. In spite of the ubiquitous references to prevalence norms and workforce differentiation in the talent management literature (e.g., Chuai et al., 2008), however, we also find quite a large number of publications advocating a more inclusive approach — especially in the literature on strengthbased talent management (e.g., Buckingham \& Vosburgh, 2001; Warren, 2006).

The inclusive-exclusive divide is to be seen as a continuum with two extremes. At the exclusive extreme, we might find organizations that allocate 90 percent of their resources (e.g., monetary and non-monetary rewards, training budgets, promotion opportunities) to 5 percent of their employees. The investment of disproportionate resources where one expects disproportionate returns - i.e., in those specific jobs and those specific people within jobs that help create strategic success - is what is referred to in the RBV literature as 'workforce differentiation' (Becker et al., 2009; Huselid \& Becker, 2011; Ledford \& Kochanski, 2004). 
At the inclusive extreme, we might find organizations that allocate all of their resources equally among employees — or even, allocate more resources to low-performing than to highperforming employee groups with the goal of achieving overall 'good' levels of performance and satisfaction (Bothner, Podolny, \& Smith, 2011).

While an inclusive approach to talent management is believed to lead to a more pleasant working environment characterized by openness, trust, and overall employee wellbeing (Warren, 2006), the exclusive approach is assumed to generate higher return on investment in terms of profit and productivity, brought about by increases in the achievement motivation of pivotal employees (Boudreau \& Ramstad, 2005).

Tension between innate vs. acquired perspectives on talent. This third tension in the literature refers to the important discussion about the extent to which talent can be taught and learned (see also Meyers, van Woerkom, \& Dries, this issue). Innate perspectives on talent imply a focus on the selection, assessment, and identification of talent. In an era of increasing talent scarcity, this means aggressively searching, recruiting, and selecting highly sought-after profiles - which is expected to become more and more challenging as scarcities become even more tangible (Cappelli, 2008). Acquired perspectives on talent, on the other hand, imply a focus on education, training, experience, and learning as tools for talent development (McCall, 1998). Although this latter perspective seems particularly attractive considering the changing demand-supply dynamics in the labor market (cf. the discussion on 'making or buying' talent), research has shown that most organizational decision makers tend to believe that talent is, for the largest part, inborn (e.g., Tsay \& Banaji, 2011).

Beliefs about talent being innate or not are influenced by a number of factors. A first factor is the implicit person theory that prevails in the organization. Whereas some organizational decision makers will believe that people "are who they are", and that the odds of people changing over time are low (i.e., entity theory), others will believe that people are 
determined primarily by the lessons they learn from experience, and that people can change even at a later age (i.e., incremental theory) (see Heslin et al., 2005). Whether a manager, or a group or managers, believes in one or the other will affect the extent to which an organization's (or a department's) talent management practices focus more on selection, or development of talented employees. It also has 'path dependency' implications, in that an entity theorist who does not see the potential of a particular employee at one point in time, is not likely to change his mind at a later time (Heslin et al., 2005). A second factor is culture. In her philological analysis of the word 'talent' from both a historical and a linguisticcomparative point of view, Tansley (2011) found that while European languages such as English, German and French stress the innate nature of talent, in Eastern languages such as Japanese talent is seen as the product of many years of hard work and striving to attain perfection.

Tension between input vs. output perspectives on talent. This fourth tension in the literature refers to the important discussion about whether talent depends more on ability or motivation. Input perspectives on talent imply a focus on effort, motivation, ambition, and career orientation in assessments of talent. Output perspectives on talent, on the other hand, imply an assessment focus on output, performance, achievements, and results. Appropriate theoretical frameworks for studying talent-as-ability are most likely to be found in the I/O psychology literature (e.g. Hough \& Oswald, 2000). The literatures on passion (see Vallerand et al., 2003) and loving one's job (see Kelloway et al., 2010) are a valuable point of departure for studying talent-as-motivation.

Research has demonstrated that most organizations focus solely on ability (typically operationalized as past performance) in their assessments of talent (Silzer \& Church, 2010). For most companies, identifying talent based on 'hard' performance data is less politically charged than identification based on motivational variables (Larsen et al., 1998). According 
to Ulrich \& Smallwood (2012), however, different elements of talent should be seen as multiplicative rather than additive - e.g., "talent $=$ competence $\times$ commitment $\times$ contribution"-in that high scores on one element (e.g., commitment) cannot compensate for low scores on another (e.g., competence). Moreover, it has been said that the aspect of motivation in general has been underappreciated in talent management research and practice. Research on career derailment, for instance, has demonstrated that many 'former high potential' leaders derail simply because they had no desire to be leaders in the first place (McCall, 1998). Also, the literature on attribution has shown that exceptional achievements attributed to effort and hard work are valued more (at least by the employees themselves) than achievements attributed to high ability alone (Tsay \& Banaji, 2011).

Tension between transferable vs. context-dependent perspectives on talent. This fifth and final tension in the literature refers to the important discussion about the extent to which talent is conditional on its environment. Transferable perspectives on talent assume that talented people will demonstrate their talent regardless of the (working) environment they are in. As a consequence, recruitment and direct search are talent management practices of choice in this type of approach (Cappelli, 2008). Context-dependent perspectives on talent, on the other hand, assume important interactions between individuals and contextsdetermining whether underlying talent emerges in reality and/or is recognized and acknowledged (Dominick \& Gabriel, 2009).

A number of often-cited management studies on the transitions of star employees to new companies (usually initiated through headhunting) have demonstrated that talent is not always transferable and that organizations cannot expect star hires to perform at their best in the first year or so after organizational entry (e.g., Groysberg, Lee, \& Nanda, 2008). A lack of fit between the star hire and his or her new environment is one possible explanation of these studies' findings (see the literature on person-environment fit; e.g. Kristof, 2006). 
Publications from outside the HRM literature have extolled the virtues of 'talent transfer', however - the transfer of talent from one performance domain to another. For instance, research in samples of professional athletes has demonstrated that talents can be identified that underlie different performance domains, and that through cross-training (i.e., the expansion of skills using different, unrelated training techniques) latent performance in a new performance domain can be brought to the surface (Bullock et al., 2009). It would be very interesting to examine whether similar results can be obtained in organizational settings. Similarly, research on a sample of scientists has found that the most eminent scientists tend to have very broad interests and are extremely versatile, working on different, unrelated projects at any given point in time and integrating knowledge acquired in different contexts (Simonton, 2000).

\section{Conjectural Assumptions about Talent Management}

In addition to the se theoretical perspectives, we also identify four types of conjectural assumptions about talent management-i.e. assumptions that appear valid at first glance, but that have yet to be proven or disproven — which are typically held by HR practitioners and that have started to resonate through the talent management literature in recent years.

Conjectural assumptions promoted by HR practitioners are less harmless as they may seem. First of all, they dictate talent management practice (Lewis \& Heckman, 2006). Second, they are often portrayed as legitimate facts and thus, contribute to the confound of discourse with empirical knowledge inherent to the literature on talent management (Iles et al., 2010b). More importantly, the identification and dissection of conjectural assumptions - in parallel to the identification of relevant theoretical perspectives in the broader literature - can serve as a basis for the development of contrasting hypotheses (see von Krogh et al., 2009).

"I know talent when I see it". A surprising amount of HR practitioners believe that valid identification of talented employees does not require formal assessment policies or even 
a formal definition of talent (e.g., Tulgan, 2001). The main reason for this type of assumption (also referred to as 'X-factor' or 'right stuff' thinking; see McCall, 1998) is the fact that organizational decision makers commonly overestimate the validity of intuitive judgment, whilst simultaneously underestimating the validity of paper-and-pencil tests, structured interviews, and assessment centers. These pervasive beliefs lie at the heart of what Highhouse (2008) calls a "stubborn reliance on intuition and subjectivity" (p. 333). The idea that personal judgment can be more valid than formal testing as long as the assessor is experienced enough is referred to as 'the myth of experience'. That is because different sources of rater bias limit the validity of subjective judgment (Highhouse, 2008) - e.g., anchoring (i.e. the general tendency of people to interpret new data in light of an existing impression), halo bias (i.e., a form of bias whereby raters do not distinguish their evaluations of candidates among relevant dimensions but rather, attribute either a positive or a negative global score to candidates), and similar-to-me bias (i.e., a preference for candidates more similar to oneself).

“Tell a person they're talented, and they become it". A typical concern about talent management is that it creates self-fulfilling prophecies, in two different ways. First of all, the identification and labeling of people as talented is believed to produce Pygmalion effects, in that the positive affirmation of being assigned the 'talent' label, through heightened self-confidence and role commitment, might lead to increases in performance (Eden, 1984). As a consequence, the criterion used to evaluate the predictive validity of the identification of a person as talented - i.e., his or her performance at a later point in time - is, at least partly, an artifact of self-fulfilling prophecy (Larsen et al., 1998). If this is true (and there has been a lot of experimental research implying that it is; see Eden, 1984), a clear implication would be that organizations should invest as much resources as possible into as many employees as possible rather than engaging in exclusive selection procedures (Buckingham \& Vosburgh, 
2001). A second type of self-fulfilling prophecy is the occurrence of 'success syndrome' (McCall, 1998) — a phenomenon whereby early career sponsorship of employees identified as talented leads to exceptional success for that cohort, without being able to separate whether the success is attributable to the employees' talent, or the additional organizational support they have received because of their talent label (see also the literature on sponsored career mobility; e.g. Ishida et al., 2002; Larsen et al., 1998).

"Tell a person they're talented, and they stop trying". In stark contrast to the literature on the Pygmalion effect is the (equally widespread) assumption of a 'crown prince' syndrome. The crown prince syndrome describes the phenomenon whereby people who believe they are assured a spot in their organizations' senior management (much like crown princes) lose their motivation to work for it (Dries \& Pepermans, 2008). Among HR practitioners, this type of assumption has led to the belief that it is better to hide from people whether or not they are seen as talented (Bournois \& Rousillon, 1992). Although there is much more empirical support for Pygmalion-type effects than for crown prince effects, beliefs of the talent label leading to arrogance and complacency are widespread among organizational decision makers (Larsen et al., 1998). In the academic world, as well, some department heads are known to be hesitant to award tenure to young professors as they believe it will lead to a decrease in achievement motivation and productivity (e.g., Yining, Gupta, \& Hoshower, 2006).

"You can't tell people you don't consider them talented". A final assumption is that it is better not to communicate openly about the talent management policies of the organization, since this would lead to frustration and dissatisfaction among employees not identified as talented (Bothner et al., 2011). According to Larsen et al. (1998), "the greater the top management attention, organizational resource, and ceremonies, the more prone others are to be jealous" (p. 74). Studies estimate that only around one in three organizations 
disclose information about their talent management policies to employees (Bournois \& Rousillon, 1992). The possible advantages of 'strategic ambiguity' were already spelled out over two decades ago by Eisenberg (1987), who stated that although a transparent communication strategy is generally the most ethical approach, it is not always strategically interesting, especially when privileged positions in the organizations need to be preserved. The literature on perceived organizational justice implies, however, that transparency about talent management procedures is a necessary precondition to improving perceptions of distributive injustice among employees not identified as talented (e.g. see also Gelens, Dries, Hofmans, \& Pepermans, this issue; Jerusalim \& Hausdorf, 2007)—moreover, HRM scholars estimate that even under conditions of strategic ambiguity, information about talent management procedures leaks to employees in 90 percent of all organizations (Bournois \& Rousillon, 1992).

\section{Discussion}

Throughout this paper, we have identified a number of discrepancies (i.e., between practitioner and academic interest; between talent management discourse and practice), different theoretical perspectives (i.e., HRM; I/O psychology; educational psychology; vocational psychology; positive psychology; social psychology), tensions (i.e., object-subject; inclusive-exlusive; innate-acquired; input-output:; transferable-context-dependent), and assumptions (i.e., about intuition versus data; about the effects of being labeled 'talented'; about the effects of differential treatment) that might each, in their own way, contribute to the theory and practice of talent management.

\section{Implications for Talent Management Research}

As discussed in the beginning of this paper, popular phenomena such as talent management can be classified as being in an embryonic, growth, mature, or declining state (von Krogh et al., 2009). The current state of the literature, as demonstrated by our 
comparative review, implies that the study of talent management is in a growing state. With this review, we hope to join an expanding group of talent management scholars pushing to make the transition from a growing into a mature field of study, characterized by widely accepted theoretical frameworks and research designs, and supported by the scholarly community (Silzer, 2010). In order to legitimize talent management as a field of academic study, however, we need more empirical work, departing either from a more phenomenon- or a more theory-driven perspective-depending on the specific research question (see Table 4). von Krogh et al. (2009) propose a protocol for phenomenon-driven research that involves five stages - i.e., distinguishing, exploring, designing, theorizing, and synthesizing.

Stage 1: Distinguishing. Distinguishing refers to the activity of giving the phenomenon (in this case, talent management) an identity, by distinguishing it from its background. Further theoretical work is necessary in order to distinguish talent management in more depth from related concepts such as SHRM, succession planning, leadership development, career management, competence management, and knowledge management (Lewis \& Heckman, 2006). We recommend that researchers interested in the study of talent management adopt a multidisciplinary approach in their conceptual work since such an approach is more likely to result in improved embeddedness of the topic of talent management in more established theoretical frameworks and in the wider academic literature (Silzer, 2010).

Stage 2: Exploring. Once distinguished and described through well-defined constructs, the phenomenon can be further explored. Exploring refers to the activity of collecting all sorts of data that may fall within the scope — or just outside of it —of the constructs chosen to describe the talent management phenomenon. This offers opportunities for establishing the boundaries of the phenomenon. The best strategy for exploration is to engage in a relatively unrestricted collection of primary data on talent management - e.g., 
interviews with different stakeholders (i.e., HR managers, line managers, middle managers, board members, CEOs, external consultants, headhunters, policy makers, employee representatives) — complemented by secondary data (e.g., news reports, online resources, personnel records, policy documents, trade publications). The purpose is to create a nomological network of talent management that will serve as an efficient filter for data in the research stages yet to come.

Stage 3: Designing. The first and the second stage of phenomenon-driven research will generate new constructs, new data, new information, and new interpretations relating to the talent management phenomenon - based on these, researchers can now start designing empirical studies. In this third stage, von Krogh et al. (2009) recommend setting up studies based on information collected about the phenomenon in se. In this stage of phenomenondriven research, hypotheses might be formulated based on the conjectural assumptions identified in the current paper, and in other phenomenon-driven publications about talent management (e.g., Collings \& Mellahi, 2009; Iles et al., 2010a; Lewis \& Heckman, 2006; Silzer \& Church, 2010). Findings from the resultant phenomenon-driven studies can subsequently inform theory, so that more theory-driven designs can be conceived in the next stages (see Stages 4 and 5).

Stage 4: Theorizing. Over time, scholars will become better judges of the extent to which the talent management phenomenon overlaps with, or deviates from existing theory. Scholars can theorize along three paths: (a), using existing theory to explain the talent management phenomenon; (b), adapting and modifying existing theory, or creating new theory through the combination of existing theories; or (c), developing new theory in those cases where (a) and (b) fail. To date, there has been little to no knowledge exchange between the different literatures identified as relevant in this comparative review as they are published in different journals, draw on different theoretical frameworks, and consist of non- 
overlapping networks of authors and research groups. Therefore, theoretical integration and advancement will not only demand comparative literature review, but also the (more or less formal) establishment of a multidisciplinary network of scholars interested in advancing academic understanding of talent management.

Stage 5: Synthesizing. In the synthesis stage, new relationships that are forged between theories and research designs may lead to the development of counter-intuitive research propositions. In this stage, the research might even start violating principles of good theory development such as consistency with earlier work and sensitivity to theoretical and methodological conventions. Synthesis is also important for assessing whether or not continued research on the phenomenon is warranted-e.g., whether or not the phenomenon is gradually maturing or rapidly declining (Iles et al., 2010a).

Based on all of the above, in Table 4 we offer some specific suggestions for research designs that might advance the academic study of talent management.

$$
\text { — Insert Table } 4 \text { about here - }
$$

\section{Implications for Talent Management Practice}

How can organizational decision makers make sense out of all of this? It is important to understand that, when it comes to talent management, no single perspective on talent is objectively better than another (Boudreau \& Ramstad, 2005). As Garrow and Hirsch (2008) assert, talent management is not a matter of best practices, but rather, of best fit-i.e. fit with strategic objectives, fit with organizational culture, fit with other HR practices and policies, and fit with organizational capacity. Consequently, the different approaches to talent management summarized in Tables 2 and 3 are all equally viable and can subsist in a myriad of configurations, each with its own merits and drawbacks. For example, an exclusive and output-oriented approach to talent management is more likely to fit well in an organization 
with a meritocratic, competitive culture and an up-or-out promotion system than in an organization that promotes egalitarianism, diversity and teamwork (Larsen et al., 1998).

Organizations need to realize that ad-hoc approaches to talent management almost always lead to discrepancies between theory and practice (Gill, 2002) — and that return on investment (ROI) cannot be assessed unless the goals of talent management are made explicit; investments and interventions are followed up centrally; and soft and hard metrics of relevant outcomes are not only collected, but also analyzed and interpreted in light of an integrated strategic framework (Boudreau \& Ramstad, 2005).

As for individual employees, they are often oddly unaware of the talent management dynamics operating within their employing organizations - even though these are likely to have crucial implications for the further course of their career (Larsen et al., 1998). Part of the explanation is that talent management procedures are often quite intransparent, with crucial information being withheld from employees (e.g., not being identified as talented) (Bournois \& Rousillon, 1992). In addition, employees (even high potential ones) are often naïve, and somewhat reactive, when it comes to managing their own careers (e.g. Dries \& Pepermans, 2008). Advances in the academic literature may help both organizations and individual employees make more sense of how strategic talent management decisions may or may not affect them. 


\section{References}

Anderson, N., Lievens, F., van Dam, K., \& Ryan, A.M. (2004). Future perspectives on employee selection: Key directions for future research and practice. Applied Psychology: An International Review, 53(4), 487-501.

Ashton, C., \& Morton, L. (2005). Managing talent for competitive advantage. Strategic HR Review, 4(5), 28-31.

Bakker, A.B., \& Schaufeli, W.B. (2008). Positive organizational behavior: Engaged employees in flourishing organizations. Journal of Organizational Behavior, 29(2), $147-154$.

Björkman, I., Ehrnrooth, M., Höglund, M., Mäkelä, K., Smale, A., \& Sumelius, J. (2013) Talent or not? Employee reactions to talent identification. Human Resource Management, forthcoming (early view online).

Bothner, M., Podolny, J. M., \& Smith, E. (2011). Organizing contests for status: The Matthew effect versus the Mark effect. Management Science, 57(3), 439-457.

Boudreau, J.W., \& Ramstad, P. (2005). Talentship and the evolution of human resource management: from professional practices to strategic talent decision science. Human Resource Planning Journal, 28(2), 17-26.

Bournois, F., \& Rousillon, S. (1992). The management of high flyer executives in France. Human Resource Management Journal, 3(1), 37-56.

Buckingham, M., \& Vosburgh, R.M. (2001). The 21st century human resources function: It's the talent, stupid! Human Resource Planning, 24(4), 17-23.

Bullock, N., Gulbin, J. P., Martin, D. T., Ross, A., Holland, T., \& Marino, F. (2009). Talent identification and deliberate programming in skeleton: Ice novice to Winter Olympian in 14 months. Journal of Sports Sciences, 27, 397-404. 
Calo, T.J. (2008). Talent management in the era of the aging workforce: The critical role of knowledge transfer. Public Personnel Management, 37(4), 403-416.

Cappelli, P. (2008). Talent on demand : Managing talent in an age of uncertainty. Boston, MA: Harvard Business School Press.

Chuai, X., Preece, D., \& Iles, P. (2008). Is talent management just "old wine in new bottles"? The case of multinational companies in Beijing. Management Research News, 31(12), 901-911.

Collings, D.G., \& Mellahi, K. (2009). Strategic talent management: A review and research agenda. Human Resource Management Review, 19(4), 304-313.

Creelman, D. (2004). Return on investment in talent management: Measures you can put to work right now. Washington, DC: Human Capital Institute research report, September.

Dries, N., \& Pepermans, R. (2008). 'Real' high potential careers: An empirical study into the perspectives of organizations and high potentials. Personnel Review, 37(1), 85-108.

Duttagupta, R. (2005). Identifying and managing your assets: Talent management. London, UK: PricewaterhouseCoopers.

Eden, D. (1984). Self-fulfilling prophecy as a management tool: Harnessing Pygmalion. Academy of Management Review, 9(1), 64-73.

Eisenberg, E.M., \& Witten, M. (1987). Reconsidering openness in organizational communication. Academy of Management Review, 12, 418-426.

Farndale, E., Scullion, H., \& Sparrow, P. (2010). The role of the corporate HR function in global talent management. Journal of World Business, 45(2), 161-168.

Gagné, F. (2004). Transforming gifts into talents: The DMGT as a developmental theory. High Ability Studies, 15(2), 119-147. 
Gallardo-Gallardo, E., Dries, N., \& González-Cruz, T. (this issue). What is the meaning of 'talent' in the world of work? Human Resource Management Review.

Garrow, V., \& Hirsch, W. (2008). Talent management: Issues of focus and fit. Public Personnel Management, 37(4), 389-402.

Gelens, J., Dries, N., Hofmans, J., \& Pepermans, R. (this issue). The role of perceived organizational justice in shaping the outcomes of talent management: A research agenda. Human Resource Management Review.

Gill, C. (2002). Two-dimensional HRM: Limitations of the soft and hard dichotomy in explaining the phenomenon of HRM. RMIT working paper, $n^{\circ} 04 / 2002$.

Graen, G. (2009). Early identification of future executives: A functional approach. Industrial and Organizational Psychology, 2, 437-441.

Groysberg, G., Lee, L., \& Nanda, A. (2008). Can they take it with them? The portability of star knowledge workers’ performance. Management Science, 54(7), 1213-1230.

Hambrick, D.C. (2007). The field of management's devotion to theory: Too much of a good thing? Academy of Management Journal, 50(6), 1346-1352.

Heslin, P.A., Latham, G.P., \& Vandewalle, D. (2005). The effect of implicit person theory on performance appraisals. Journal of Applied Psychology, 90(5), 842-856.

Highhouse, S. (2008). Stubborn reliance on intuition and subjectivity in employee selection. Industrial and Organizational Psychology, 1, 333-342.

Höglund, M. (2012). Quid pro quo? Examining talent management through the lens of psychological contracts. Personnel Review, 41(2), 126-142.

Hough, L.M., \& Oswald, F.L. (2000). Personnel selection: Looking toward the future remembering the past. Annual Review of Psychology, 51, 631-664. 
Huang, J., \& Tansley, C. (2012). Sneaking through the minefield of talent management: The notion of rhetorical obfuscation. The International Journal of Human Resource Management, 23(17), 3673-3691.

Huselid, M.A., \& Becker, B.E. (2011). Bridging micro and macro domains: Workforce differentiation and strategic human resource management. Journal of Management, $37(2), 421-428$.

Ibarra, H. (1999). Provisional selves: Experimenting with image and identity in professional adaptation. Administrative Science Quarterly, 44(4), 764-792.

Iles, P. (1997). Sustainable high potential career development: A resource-based view. Career Development International, 2(7), 347-353.

Iles, P., Chuai, X., \& Preece, D. (2010b). Talent management and HRM in multinational companies in Beijing: Definitions, differences and drivers. Journal of World Business, $45,179-189$.

Iles, P., Preece, D., \& Chuai, X. (2010a). Talent management as a management fashion in HRD: Towards a research agenda. Human Resource Development International, $13(2), 125-145$.

Inkson, K. (2008). Are humans resources? Career Development International, 13(3), 270279.

Ishida, H., Su, K., \& Spilerman, S. (2002). Models of career advancement in organizations. European Sociological Review, 18(2), 179-198.

Jerusalim, R.S., \& Hausdorf, P.A. (2007). Managers' justice perceptions of high potential identification practices. Journal of Management Development, 26(10), 933-950.

Kelloway, E.K., Inness, M., Barling, J., Francis, L., \& Turner, N. (2010). Loving one's job: Construct development and implications for individual well-being. Research in Occupational Stress and Well-Being, 8, 109-136. 
Kristof, A.L. (1996). Person-environment fit: An integrative review of its conceptualizations, measurement, and implications. Personnel Psychology, 49(1), 1-49.

Larsen, H.H., London, M., Weinstein, M., \& Raghuram, S. (1998). High-flyer management development programs: Organizational rhetoric or self-fulfilling prophecy? International Studies of Management \& Organization, 28(1), 64-90.

Ledford, G., \& Kochanski, J. (2004). Allocating training and development resources based on contribution. In L. Berger, \& D. Berger (Eds.), The talent management handbook: Creating organizational excellence by identifying, developing and promoting your best people (pp. 218-229). New York, NY: McGraw-Hill.

Lepak, D.P., \& Snell, S.A. (1999). The human resource architecture: Toward a theory of human capital allocation and development. Academy of Management Review, 24(1), $31-48$.

Lewis, R., \& Heckman, R. (2006). Talent management: A critical review. Human Resource Management Review, 16(2), 139-154.

Marescaux, E., De Winne, S., \& Sels, L. (2013). HR practices and affective organisational commitment: (When) does HR differentiation pay off? Human Resource Management Journal, forthcoming (early view online).

Markus, H., \& Nurius, P. (1986). Possible selves. American Psychologist, 41(9), 954-969.

McCall, M.W. (1998). High flyers: Developing the next generation of leaders. Boston, MA: Harvard Business School Press.

Meyers, M.C., van Woerkom, M., \& Dries, N. (this issue). Talent-innate or acquired? Theoretical considerations and their implications for talent management. Human Resource Management Review.

Michaels, E., Handfield-Jones, H., \& Axelrod, B. (2001). The war for talent. Boston, MA: Harvard Business School Press. 
Oettingen, G., Marquardt, M.K., \& Gollwitzer, P.M. (2012). Mental contrasting turns feedback on creative potential into successful performance. Journal of Experimental Social Psychology, 48, 990-996.

Pascal, C. (2004). Foreword. In A. Schweyer (Ed.), Talent management systems: Best practices in technology solutions for recruitment, retention and workforce planning. San Francisco, CA: John Wiley \& Sons.

Remdisch, S., \& Dionisius, S. (1998). Training supervisors' assessment skills - a crucial step in high potential selection. European Journal of Work and Organizational Psychology, $7(4), 559-564$.

Robinson, C., Fetters, R., Riester, D., \& Bracco, A. (2009). The paradox of potential: A suggestion for guiding talent management discussions in organizations. Industrial and Organizational Psychology, 2, 413-415.

Rousseau, D.M. (2001). Schema, promise and mutuality: The building blocks of the psychological contract. Journal of Occupational and Organizational Psychology, 74, $511-541$.

Seligman, M., \& Csikszentmihalyi, M. (2000). Positive psychology: An introduction. American Psychologist, 55, 5-14.

Silzer, R. (2010). Critical research issues in talent management. In R. Silzer \& B.E. Dowell (Eds.), Strategy-driven talent management: A leadership imperative (pp. 767-780). San Francisco, CA: Jossey-Bass.

Silzer, R., \& Church, A.H. (2009). Identifying and assessing high-potential talent: Current organizational practices. In R. Silzer \& B.E. Dowell (Eds.), Strategy-driven talent management: A leadership imperative (pp. 213-279). San Francisco, CA: Jossey-Bass.

Simonton, D.K. (1999). Talent and its development: An emergenic and epigenetic model. Psychological Review, 106(3), 435-457. 
Sloan, E.B., Hazucha, J.F., \& Van Katwyk, P.T. (2003). Strategic management of global leadership talent. In W.H. Mobley, \& P.W. Dorfman (Eds.), Advances in global leadership (vol. 3, pp. 235-274). New York, NY: JAI.

Sparrow, P.R. (2009, Oct.). When is talent not talent? Talent Management Review, 18-20.

Spreitzer, G.,\& Sonenshein, S. (2004). Toward the construct definition of positive deviance. Applied Behavioral Scientist, 77(6): 838-847.

Tansley, C. (2011). What do we mean by the term "talent" in talent management? Industrial and Commercial Training, 43(5), 266-274.

Truss, C., Gratton, L., Hope-Hailey, V., McGovern, P., \& Stiles, P. (1997). Soft and hard models of human resource management: A reappraisal. Journal of Management Studies, $34,53-73$.

Tsay, C., \& Banaji, M.R. (2011). Naturals and strivers: Preferences and beliefs about sources of achievement. Journal of Experimental Social Psychology, 47, 460-465.

Tucker, E., Kao, T., \& Verma, N. (2005). Next-generation talent management: Insights on how workforce trends are changing the face of talent management. Business Credit, 107, 20-27, July-August.

Tulgan, B. (2001). Winning the talent wars. Employment Relations Today, 23(1-2), 37-51.

Ulrich, D., \& Smallwood, N. (2012). What is talent? Leader to Leader, 63, 55-61.

Vallerand, R.J., Blanchard, C., Mageau G.A., Koestner R., Ratelle, C., Leonard, M., Gagné, M., \& Marsolais, J. (2003). Les passions de l'âme: On obsessive and harmonious passion. Journal of Personality and Social Psychology, 85(4), 756-67.

Von Krogh, G., Lamastra, C.R., \& Haefliger, S. (2009). Phenomenon-based research in management and organization science: Towards a research strategy. ETH Zurich: Working paper.

Warren, C. (2006). Curtain call: Talent management. People management, 24-29, March. 
Whitty, M. (2002). Possible selves: Exploring the utility of a narrative approach. Identity: An International Journal of Theory and Research, 2(3), 213-230.

Wood, A.M., Linley, P.A., Maltby, J., Kashdan, T.B., \& Hurling, R. (2011). Using personal and psychological strengths leads to increases in well-being over time: A longitudinal study and the development of the strengths use questionnaire. Personality and Individual Differences, 50, 15-19.

Wright, P.M., \& Nishii, L.H. (2007). Strategic HRM and organizational behavior: Integrating multiple levels of analysis. CAHRS Working Paper Series, paper 468, 126.

Yining, C., Gupta, A., \& Hoshower, L. (2006). Factors that motivate business faculty to conduct research: An expectancy theory analysis. Journal Of Education For Business, 81(4), 179-189. 


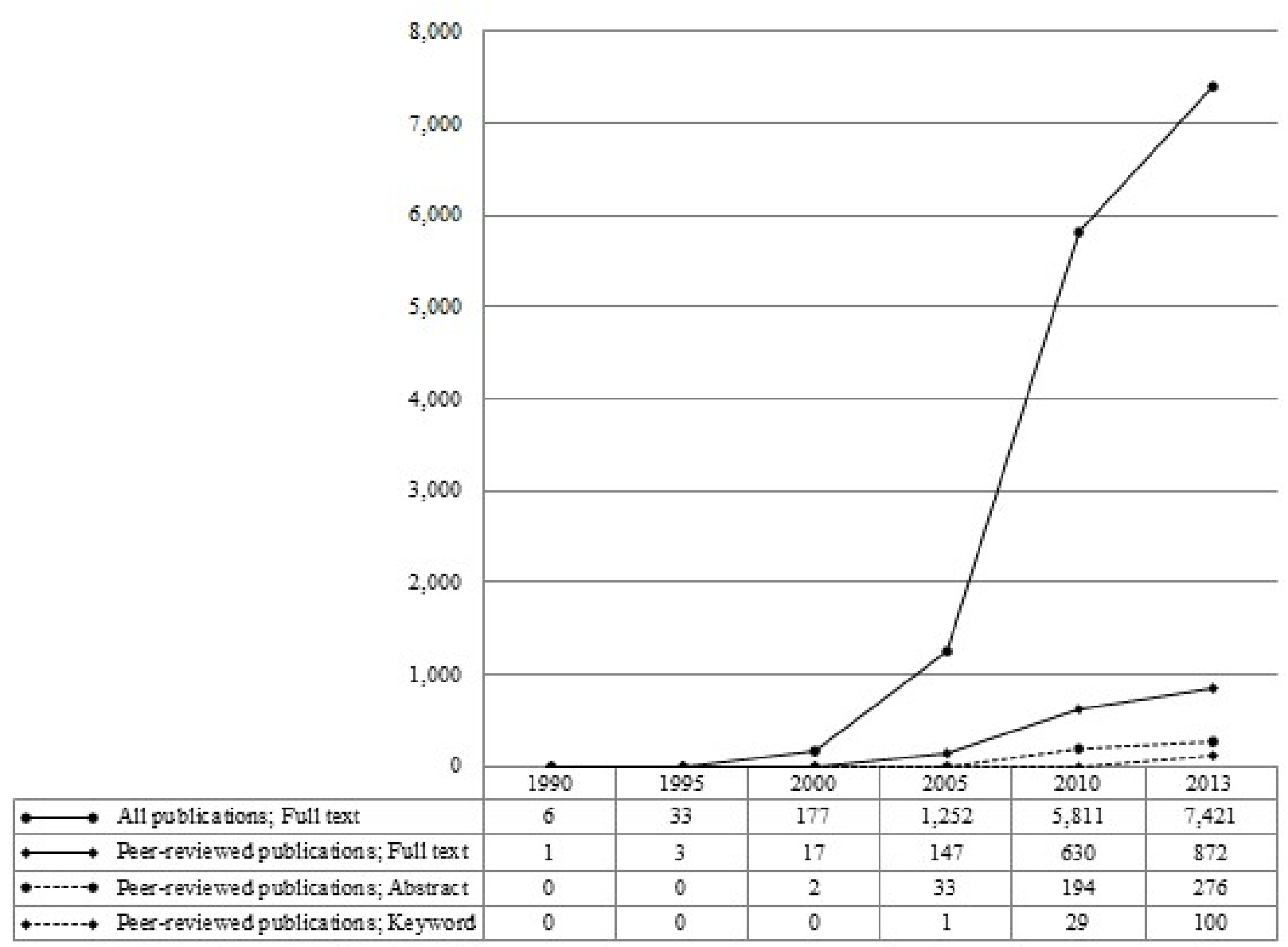

Figure 1. Bibliometric curve of the number of publications referring to talent management between 1990 and 2013.

(Database: Business Source Premier) 


\section{THE PSYCHOLOGY OF TALENT MANAGEMENT}

Table 1.

\section{Definitions of Talent Management Found in the HRM Literature}

\begin{tabular}{|c|c|c|}
\hline \multicolumn{2}{|c|}{ Reference } & \multirow{2}{*}{$\begin{array}{l}\text { Definition of talent management } \\
\text { "Managing leadership talent strategically, to put the right person in the right place at the right time" (p. 236) }\end{array}$} \\
\hline 2003 & Sloan, Hazucha, \& Van Katwyk & \\
\hline 2004 & Pascal & "Talent management encompasses managing the supply, demand, and flow of talent through the human capital engine" (p. 9) \\
\hline 2005 & Ashton \& Morton & $\begin{array}{l}\text { "TM is a strategic and holistic approach to both HR and business planning or a new route to organizational effectiveness. This improves the } \\
\text { performance and the potential of people - the talent—-who can make a measurable difference to the organization now and in future. And it aspires to } \\
\text { yield enhanced performance among all levels in the workforce, thus allowing everyone to reach his/her potential, no matter what that might be" (p. } \\
\text { 30) }\end{array}$ \\
\hline 2005 & Duttagupta & $\begin{array}{l}\text { "In the broadest possible terms, TM is the strategic management of the flow of talent through an organization. Its purpose is to assure that a supply of } \\
\text { talent is available to align the right people with the right jobs at the right time based on strategic business objectives" (p. } 2)\end{array}$ \\
\hline 2006 & Warren & $\begin{array}{l}\text { "In its broadest sense, the term can be seen as the identification, development, engagement, retention and deployment of talent, although it is often } \\
\text { used more narrowly to describe the short- and longer-term resourcing of senior executives and high performers" (p. 26) }\end{array}$ \\
\hline 2007 & Jerusalim \& Hausdorf & $\begin{array}{l}\text { "High potential identification and development (also known as talent management) refers to the process by which an organization identifies and } \\
\text { develops employees who are potentially able to move into leadership roles sometime in the future" (p. 934) }\end{array}$ \\
\hline 2008 & Cappelli & "At its heart, talent management is simply a matter of anticipating the need for human capital and setting out a plan to meet it" (p. 1) \\
\hline 2009 & Collings \& Mellahi & $\begin{array}{l}\text { "We define strategic talent management as activities and processes that involve the systematic identification of key positions which differentially } \\
\text { contribute to the organization's sustainable competitive advantage, the development of a talent pool of high potentials and high-performing } \\
\text { incumbents to fill these roles, and the development of a differentiated human resource architecture to facilitate filling these positions with competent } \\
\text { incumbents and to ensure their continued commitment to the organization" (p. 2) }\end{array}$ \\
\hline 2010 & Silzer \& Dowell & $\begin{array}{l}\text { "Talent management is an integrated set of processes, programs, and cultural norms in an organization designed and implemented to attract, develop, } \\
\text { deploy, and retain talent to achieve strategic objectives and meet future business needs" (p. 18) }\end{array}$ \\
\hline
\end{tabular}

Note. $\mathrm{TM}=$ talent management 


\section{THE PSYCHOLOGY OF TALENT MANAGEMENT}

\section{Table 2.}

Summary of Relevant Theoretical Perspectives on Talent

\begin{tabular}{|c|c|c|c|c|}
\hline Literature stream & Operationalization of talent & Main criterion & Main contribution & Main gap \\
\hline HRM & Talent as capital & Contribution to organization & Links individual talent to organizational context & Lack of theory and empirical evidence \\
\hline I/O psychology & Talent as individual difference & Predictive validity & $\begin{array}{l}\text { Long research tradition in personnel selection, } \\
\text { promotion systems, and performance appraisal }\end{array}$ & Criterion problem—talent for what? \\
\hline Educational psychology & Talent as giftedness & Domain-specific excellence & Strong (causal) theoretical frameworks & $\begin{array}{l}\text { Mostly conceptual work; no research in adult } \\
\text { populations }\end{array}$ \\
\hline Vocational psychology & Talent as identity & Self-concept crystallization & $\begin{array}{l}\text { Recognition of the dynamic nature of talent, as a } \\
\text { construct, over the course of a person's life }\end{array}$ & $\begin{array}{l}\text { Mostly narrative research; difficult to reconcile } \\
\text { with more positivistic approaches }\end{array}$ \\
\hline Positive psychology & Talent as strength & Self-actualization & $\begin{array}{l}\text { Treats positive outliers as research subjects of } \\
\text { choice, rather than measurement error }\end{array}$ & $\begin{array}{l}\text { Assumption of strength-based approach as 'win- } \\
\text { win' for individuals and organizations }\end{array}$ \\
\hline Social psychology & Talent as the perception of talent & Rater accuracy & $\begin{array}{l}\text { Brings in element of social perception-i.e., } \\
\text { talent that is not acknowledged does not 'exist' }\end{array}$ & $\begin{array}{l}\text { Generalization of experimental findings to real- } \\
\text { life settings? }\end{array}$ \\
\hline
\end{tabular}




\section{THE PSYCHOLOGY OF TALENT MANAGEMENT}

\section{Table 3 .}

\section{Tensions in the Literature about Talent}

\begin{tabular}{|c|c|c|c|}
\hline Key point of discussion & Practical TM issue & Tensions & Implications for TM policies and practices \\
\hline \multirow[t]{2}{*}{ What (or who) is talent? } & What should TM manage? & Object & Competence management, knowledge management \\
\hline & & Subject & Organizational career management, succession planning \\
\hline \multirow[t]{2}{*}{ How prevalent is talent in the population? } & By which principle should organizations allocate their resources? & Inclusive & Strength-based approach \\
\hline & & Exclusive & Workforce differentiation \\
\hline \multirow[t]{2}{*}{ Can talent be taught (and learned)? } & How can organizations tackle labor market scarcities? & Innate & Selection, assessment, identification \\
\hline & & Acquired & Development, experience, learning \\
\hline \multirow{2}{*}{ Is talent more about ability or motivation? } & What should organizations select for? & Input & Effort, motivation, ambition, career orientation \\
\hline & & Output & Output, performance, achievement, results \\
\hline \multirow[t]{2}{*}{ Is talent conditional on its environment? } & Should organizations recruit externally or internally? & Transferable & Recruitment-identification prior to entry \\
\hline & & Context-dependent & Fit-identification only after a certain socialization period \\
\hline
\end{tabular}

Note. $\mathrm{TM}=$ talent management. 


\section{THE PSYCHOLOGY OF TALENT MANAGEMENT}

\section{Table 4.}

\section{Suggested Research Designs for the Further Study of Talent Management}

\begin{tabular}{|c|c|}
\hline Type of study & Suggestions for topics \\
\hline Literature reviews & $\begin{array}{l}\text { - The identification of relevant constructs and theories for the study of talent management } \\
\text { - The development of testable research propositions }\end{array}$ \\
\hline Critical discourse analysis & $\begin{array}{l}\text { - The examination of talent management discourse to distinguish TM from other constructs } \\
\text { - The development of contrasting hypotheses based on conjectural assumptions about TM } \\
\text { - The examination of different conceptions different (categories of) people have of 'talent' }\end{array}$ \\
\hline Interview studies & $\begin{array}{l}\text { - The managerial rationale behind different approaches to TM } \\
\text { - The psychological reactions of individual employees to TM practices } \\
\text { - The perspectives of different stakeholders in the TM process }\end{array}$ \\
\hline Narrative studies & $\begin{array}{l}\text { - The utility of 'possible selves' exercises in (self-)assessments of talent } \\
\text { - The examination of vocational self-concept crystallization over time }\end{array}$ \\
\hline Biographical studies & - The retroactive examination of the processes through which people achieve self-actualization (i.e., fulfill their talents) \\
\hline Cross-sectional studies & $\begin{array}{l}\text { - The prevalence of different types of TM practices in a diverse sample of organizations } \\
\text { - Relationships between TM practices and other characteristics of organizations (e.g., culture, strategy, size, core business) }\end{array}$ \\
\hline Longitudinal studies & $\begin{array}{l}\text { - The predictive validity of different talent identification criteria and assessment methods over time } \\
\text { - The growth curves (i.e., malleability) of different aspects of talent over time }\end{array}$ \\
\hline Diary studies & $\begin{array}{l}\text { - The longitudinal examination of the processes through which people achieve self-actualization over time } \\
\text { - The shortitudinal examination of the processes through which people achieve episodes of peak performance }\end{array}$ \\
\hline Multilevel studies & $\begin{array}{l}\text { - The interaction of organizational (e.g., culture, communication climate), team-level, (e.g., person-team fit, } \\
\text { homogeneity/heterogeneity, implicit person theories) and individual (e.g., satisfaction, commitment, performance) variables } \\
\text { - The development of a systems typology and optimal fit propositions linking TM approaches to organizational } \\
\text { characteristics }\end{array}$ \\
\hline Intervention studies & $\begin{array}{l}\text { - The effects of changes in TM strategy (e.g., from an inclusive to an exclusive approach; from ambiguous to transparent } \\
\text { communication) on individual- (e.g., satisfaction, commitment, performance) and organizational-level (e.g., profit, market } \\
\text { position, reputation) outcomes } \\
\text { - The examination of the feasibility of 'talent transfer' in an organizational context }\end{array}$ \\
\hline Experimental studies & $\begin{array}{l}\text { - The validity and reliability of multisource designs in assessments of talent } \\
\text { - The interaction of rater and ratee characteristics (e.g., ability, knowledge, personality, mindset) in assessments of talent } \\
\text { - The effects of accurate and bogus feedback on repeated self- and other-assessments of talent }\end{array}$ \\
\hline
\end{tabular}

